\title{
Reducing conditions in soil of Gallocanta Lake, NE Spain
}

2

3 C. CASTAÑEDA ${ }^{a}$, E. LUNA ${ }^{a} \&$ M. RABENHORST ${ }^{b}$

4

$5 \quad$ a Estación Experimental de Aula Dei, EEAD-CSIC, Ave. Montañana 1005, 50059

6 Zaragoza, Spain, ${ }^{\mathrm{b}}$ Department of Environmental Science and Technology, University of

7 Maryland, 1109 HJ Patterson Hall, College Park, MD 20740, USA

8

9 Correspondence: C. Castañeda. E-mail: ccastaneda@eead.csic.es

10

II Short title: Reducing conditions in soil

12 
I4 Saline wetlands have received limited attention only from researchers, and this neglect

I5 has often resulted in their degradation, limited conservation, and insufficient

16 information to design conservation and management plans. Gallocanta Lake is a Natural

17 Reserve of international importance for winter birds although soil resources, which

I8 support of endemisms and protected habitats, have been recognized more recently. The

19 soil of Gallocanta Lake undergoes strong oscillations of saturation and drainage followed by drying because of irregular rain and variable flooding conditions associated

2I with fluctuations in the level of the lake. This study examined reducing conditions and morphological indicators of reduction of soils around the lake with indicators of reduction in soils (IRIS) tubes, which are coated with iron oxides. We surveyed five sites for between 22 and 34 weeks. The average amount of iron removed from the IRIS tubes during the period studied ranged between 4 and $96 \%$. The intensity of reduction in the soil differs according to subtle topographic differences between sites; it increases with the decrease in elevation. The large soil salinity (ECe from 18.1 to $182 \mathrm{dS} \mathrm{m}^{-1}$ ), carbonate-rich composition (from 18.4 to $69.7 \% \mathrm{CCE}$ ) and overall small organic matter content (from 0.4 to $6.2 \% \mathrm{OM}$ ) do not seem to constrain iron mobilization because of the reducing conditions. Differences in iron depletion and patterns on the IRIS tubes show the heterogeneity of soil conditions and the complexity of factors involved in redox processes. Further research is needed to gain knowledge of the redox processes in the context of pedogenesis in semiarid lacustrine environments.

Keywords: hydromorphic soils, indicator of reduction in soils (IRIS) tubes, lacustrine, semiarid, soil micromorphology, soil reduction, soil salinity 
Highlights:

- How intermittently exposed soils are expressing the redox conditions?

- Current reducing conditions are evidenced in a fluctuating saline lake by IRIS tubes

- Soil reduction occurs in alkaline soils with intermittent waterlogging

- IRIS tubes are suitable field indicators of soil reducing conditions heterogeneity in saline lakes

\section{Introduction}

Most recent studies of water levels of the Gallocanta Lake have focused on the effects of climatic and hydrological changes (Comín et al., 1983; Rodó et al., 2002). Few studies have focused on morphological changes in saline soil of shallow fluctuating lakes, where pedogenesis is strongly related to the water level of the lake. The intermittent desiccation of Gallocanta lake, especially during the last few decades because of the decrease of rainfall (Luna et al., 2016), has favoured the succession of subaqueous and oxidizing conditions in the soil that leads to variable saturation. Redoximorphic features in Gallocanta Lake have been described recently in lakebed sediments and soil, and also in the peripheral agricultural soil (Castañeda et al., 2015).

Reducing soil conditions related to anaerobic conditions have agronomic, ecologic and environmental significance, and their importance to wetland functions is widely recognized (Craft, 2001). The reducing conditions in soil are of interest for delineating wetland soil or to confirm the hydric conditions of soil for regulatory purposes (Rabenhorst, 2008). The occurrence of redoximorphic features is a key in many international soil classification systems to infer reducing conditions in soil (reviewed by Dorau \& Mansfeldt, 2015). A field method for identifying reducing conditions in soil 
63 based on the indicator of reduction in soils (IRIS) tubes was developed by Jenkinson \&

64 Franzmeier (2006), adapted by Rabenhorst \& Burch (2006) and evaluated in floodplain areas by Castenson \& Rabenhorst (2006). This field method has been approved by the National Technical Committee for Hydric Soils (NTCHS) as a standard method and

67 field indicator of reduced soil conditions in the USA (Rabenhorst, 2012) in wetland

68 delineations. The IRIS tubes have been used for to document reducing conditions in wetland soil (Rabenhorst, 2008; Dorau \& Mansfeldt, 2015; Dorau et al., 2016) and, less frequently, in agricultural soil (Costantini et al., 2009).

Redox reactions affect pedogenetic processes and reflect hydrological functioning in the landscape. Even if landscape position is a consistent indicator of hydric soil in wetlands, wetland soil in semiarid regions is problematic and has been studied much less than those of humid regions. Semiarid wetlands undergo strong fluctuations of the water table because of the irregular rain and are frequently saline $\left(3-50 \mathrm{~g} \mathrm{l}^{-1}\right)$ or hypersaline (> $50 \mathrm{~g} \mathrm{l}^{-1}$ ) (Williams, 2002; Castañeda \& Herrero, 2008). The dearth of inventories of saline wetlands, and maps of soil and vegetation, hampers the understanding of their ecological functions and hydric behavior. The limited amount of available information results in little regulatory recognition and in wetland degradation (Williams, 2002; Castañeda \& Herrero, 2008). There has been little research on the processes of oxidation and reduction in the soil of saline wetlands although the factors that control the interactive effects of salinity and oxidation and reduction of iron under laboratory (Cameron et al., 1984; King \& Garey, 1999) or field (Snyder et al., 2004) conditions have been published. saturated and reduced. Moreover, the development of redox features is only indirectly related to how long soil has been saturated. Therefore, in the absence of site-specific 
data on water table levels in Gallocanta Lake, we required a method that reflects the current reducing conditions in the soil. Our aims were to identify the reducing conditions of soil that are currently subjected to intermittent flooding in Gallocanta Lake, to relate the degree of reduction to soil characteristics and to test the applicability of IRIS tubes as a strategy for recognizing hydric soil in such semiarid conditions.

\section{Study area}

Gallocanta Lake, NE Spain, is the largest and best preserved saline lake in Western Europe. It has been included in the Ramsar list since 1994 and is protected under the European Union (EU) Birds and Habitats Directives. The lake is in a Quaternary depression at the bottom of a karst polje within the Iberian Range at $1000 \mathrm{~m}$ a.s.l. (Figure 1). The underlying Triassic lutites and interbedded evaporites contribute both to the high salinity of the lake, which is characterized by alternating wet and dry periods, and also to the subsequent variation in soil salinity (Castañeda et al., 2015) and water chemistry (Comín et al., 1983).

The climate is dry semiarid with very irregular rainfall. The mean annual precipitation for the last 70 years is $488 \mathrm{~mm} \mathrm{yr}^{-1}$; it ranges from $761 \mathrm{~mm}$ (in 1959) to $232 \mathrm{~mm}$ (in 2001). Mean temperature is $11.4{ }^{\circ} \mathrm{C}$ for the period $1969-2015$, with 111 frost days per year. The mean annual water deficit is $605 \mathrm{~mm}$ (García-Vera \& MartínezCob, 2004) which is exacerbated by the frequent winds. The soil temperature regime is mesic, and the soil moisture regime is generally aquic at the lake shore and xeric in agricultural areas (Soil Survey Staff, 2014).

Water level fluctuation has received much attention, mainly because it can be used to identify Quaternary climatic and environmental changes (Schütt, 1998). As compiled by Luna et al. (2016), the highest water level was registered in 1974 at 2.84-m depth, 
II3 whereas during periods of low rainfall, which have been common in the last few

II4 decades, all of the free water of the lake has evaporated.

116 Methodology

II7 Selection of sites

II8 We designed a purposive sampling scheme to detect redox conditions around the lake.

119 We selected sites that flood intermittently based on a review of historical aerial I20 photographs and Landsat images, geomorphic and pedological evidence (Castañeda et

I2I al., 2015), and our field work that extended from 2009 to the present. Our selection I22 criteria required that the sites be undisturbed and accessible. At the time of the survey I23 most sites were dry. Historic photographs and satellite images provide a glimpse of the I24 conditions of the sites through time. The study sites were in different geomorphic units which include lacustrine terraces, lake bed and silt-sand barriers (Figure 1 and Table 1).

I28 The IRIS tubes used to document the development of reducing conditions in soil are 129 coated with an iron oxide suspension and the coating is dried afterwards (Castenson \& Rabenhorst, 2006; Jenkinson \& Franzmeier, 2006). Under water saturated, anaerobic and chemically reduced conditions, this coating is reduced by heterotrophic microbes and then solubilized and stripped from the tubes.

133 Five or three IRIS tubes have been used as replicates (Rabenhorst, 2008; Dorau et I34 al. 2016, respectively) to account for soil heterogeneity. Sets of five IRIS tubes $60-\mathrm{cm}$ I35 long with the lower $50 \mathrm{~cm}$ coated were installed at each site (Figure 1) between April and July 2014. Five tubes were arranged in a cluster pattern within a one square metre 137 area following the procedure of Rabenhorst (2008). The tubes were inserted into auger 
I38 holes made in the soil with a 22-mm push probe. Instead of the four-week period used

I39 for basic monitoring with IRIS tubes (Rabenhorst, 2008), we left the tubes in place for

I40 between 22 and 34 weeks (Table 1). The removal of iron oxide was monitored every

I4I four weeks. This was done by examining the central tube (carefully removed and gently

I42 reinserted to avoid abrasion) of all sets for visual evidence of removal of the iron oxide

I43 coating. We retrieved the tubes in January 2015, except the set at site 5, which was

I44 retrieved in March when the surface water evaporated and the site was easily reached.

I45 Each tube was washed gently in the field with tap water to remove any soil that adhered,

I46 and then the tube was photographed three times with the tube rotated $120^{\circ}$ between

147 each. Photography was done in the field to record the black mottles of iron

I48 monosulphide (FeS) coating (Rabenhorst et al., 2010; Dorau et al., 2016) which are

I49 metastable minerals under aerated conditions.

I50 The tubes were also y photographed systematically in the laboratory under

I5I vertical view with a fixed field of vision. The three photos of each tube were cropped

I52 and combined into a single digital image of the whole surface of the tube, and their

I53 cylindrical shape was projected into an equivalent plane. Black mottles on the IRIS

I54 tubes were quantified from the field photographs. The removal of iron oxide coating

I55 (Rabenhorst \& Burch, 2006) was quantified for each binary image that was converted

I56 digitally. For each IRIS tube, the area of maximum removal of the iron oxide coating

157 was calculated within the upper $30 \mathrm{~cm}$ of the tube, for a zone of $15 \mathrm{~cm}$ (Rabenhorst, 158 2008).

160 Laboratory analysis

16I The soil was sampled by auger ( $7 \mathrm{~cm}$ in diameter), except at sites 4 and 5 whose 162 profiles were sampled and described in pits following Schoeneberger et al. (2012). Soil 
I63 samples were air-dried at room temperature before placing in an oven at $\leq 40{ }^{\circ} \mathrm{C}$, and

164 sieved through a 2-mm mesh. Soil salinity was measured as the electrical conductivity

165 of the 1:5 soil:water extract (EC1:5) and the saturated paste extract (ECe). Electrical

166 conductivities were expressed in $\mathrm{dS} \mathrm{m}^{-1}$ at $25^{\circ} \mathrm{C}$. Calcium carbonate equivalent (CCE)

167 was determined by the Bernard calcimeter method based on the reaction with $\mathrm{HCl}$,

168 gypsum content was quantified by thermogravimetric analysis (Artieda et al., 2006) and 169 organic matter (OM) was quantified by chromic-acid digestion (Heanes, 1984) and a

170 UV/V UNICAM 8625 (Unicam Instruments Ltd., Cambridge, UK) spectrophotometer.

I7I Particle-size distribution was assessed by laser diffraction (Malvern MASTERSIZER

172 2000, Malver, UK). The $\mathrm{pH}$ and $\mathrm{EC}$ of groundwater samples were measured with a $\mathrm{pH}$

173 electrode and a conductivity cell (Orion 9157BNMD and Orion 013605MD,

174 respectively, Thermo Fisher Scientific Inc., Beverly, US) and major ions were 175 determined by ion chromatography (Metrohm 861 Advanced compact IC, Metrohm 176 AG, Herisau, Switzerland).

177 Surface soil samples $(0-10 \mathrm{~cm})$ at sites 4 and 5 that appeared black and smelled of 178 sulphur were incubated in the laboratory under aerobic conditions for 18 weeks, and $\mathrm{pH}$ 179 was measured weekly following the method of Creeper et al. (2012) and Grealish et al. I80 (2010). Undisturbed blocks of soil from selected horizons were impregnated with a I8I cold-setting polyester resin, and thin sections $(135 \mathrm{~mm} \times 58 \mathrm{~mm}$ and $58 \mathrm{~mm} \times 42 \mathrm{~mm})$ I82 were prepared by the method of Guilloré (1985) and described under polarizing I83 microscope following Stoops (2003).

185 Results

I86 Rainfall data during the survey 
I87 Based on annual rainfall and following the criteria of the Soil Survey Staff (2014), the I88 year 2014 and years immediately preceding it would be considered to be 'normal' I89 precipitation years. The rainfall registered in 2014 at the lake border in Picos weather station (Figure 1) was $377 \mathrm{~mm}, 23 \%$ less than the long-term mean of $488 \mathrm{~mm}$. The meteorological conditions during the study were characterized by a dry spring, with only $53.7 \mathrm{~mm}$ of rain from March to May. The autumn was more humid than spring, with $110 \mathrm{~mm}$ of rain from September to November. Observations of the depth of the water table indicated that it dropped during spring and summer of 2014, and it did not return to within $50 \mathrm{~cm}$ of the soil surface. The low spring rainfall together with the dryness (low level) of the lake caused a delay in the extraction of the tubes until after

197 the autumn.

Main soil features

200

The soil is strongly saline (Table 2), with an ECe up to four times the salinity of the ocean water $\left(182 \mathrm{dS} \mathrm{m}^{-1}\right)$, and has a large CCE content that ranges from 18 to $70 \%$. Soil

$202 \mathrm{pH}$ is mostly in the range between 7.6 and 8.6 and is probably dominated by of the large

203 CCE content. There is little organic matter in the soil of the lake fringes, $<2 \%$, whereas it reaches 6.2 and $5.8 \%$, at the lake bottom (site 5) and where there are saline grasses (site 1), respectively. The particle-size distribution indicates that soil texture is essentially clay loam and sand content decreases with depth. Occasionally, gravels accumulate in surface and subsurface horizons in areas where fluvial water enters the lacustrine system (site 3).

The available descriptions of soil morphology in the area (Castañeda et al., 2015;

210 Luna et al., 2016) indicate waterlogging or restricted drainage, with Gypsic Aquisalids 2II at the lake bottom (Figure 2), Typic Aquisalids at the shoreline and Typic Calcixerepts 
212 in slightly elevated areas (Table 1). The soil at the lowest topographic positions (sites 4

213 and 5) is a hydric soil that conforms to the field indicator requirements established by

214 USDA-NRCS (2010). At site 4, two horizons (Ag and 2Cg1) have a field indicator F3,

2 I5 'depleted matrix' (USDA-NRCS, 2010), with a grey matrix colour (2.5Y and chroma $\leq$

216 2), and common redox mottles (7.5YR and 10YR, Table 2). At site 5, the profile has a

217 gleyed and an iron-depleted matrix with bluish, low chroma matrix colours (10B and

$2182.5 \mathrm{GY}$ and chroma $<2$, Table 2), consistent with the field indicator F2, 'gleyed matrix'

219 (USDA-NRCS, 2010). Redox depletions (5Y and 10B) are abundant and are mainly associated with the occurrence of gypsum layers.

Micromorphic pedofeatures related to redox processes in soil on the lake floor

222 include impregnated redoximorphic features such as banded iron and manganese oxide hypocoatings. Coatings adjacent to voids occur in the soil of the surface horizon (Ayzg horizon) where the abundance of biological remains favours the formation of a channel to lenticular soil microstructure (Figure 2c). Accumulation of iron sulphides as

226 framboids, frequently clustered (Figure 2d), are common in subsurface horizons (Cyg3 227 horizon) with a massive to vughy microstructure and micritic cristalitic b-fabric as defined by Stoops (2003).

Groundwater characteristics

23I On the dates that the IRIS tubes were installed, observed water table depth ranged from $232-10 \mathrm{~cm}$ (site 1) to $-100 \mathrm{~cm}$ (site 5) (Table 1). Free surface water occurred intermittently 233 at all sites during the study period. Groundwater is non-saline in the marsh (saline 234 grasses) and reed bed areas, sites 1 and 3. The current lake bed (sites 4 and 5) and the 235 SE terrace (site 2), show similar groundwater characteristics, with a $\mathrm{pH}$ of between 6.7 236 and 7.1 and high salinity (although with a two-fold difference in EC among the 
237 unvegetated lakebed sites) with increased $\mathrm{Mg}^{2+}$ and $\mathrm{SO}^{2-}$ concentrations (Table 1).

238 Nitrates are more abundant in saline groundwater, in particular at sites 2 and 4 . The 239 bicarbonate content is somewhat variable, with a 2- to 3-fold range between the 240 maximum $\left(854 \mathrm{mg} \mathrm{l}^{-1}\right)$ at site 2 and the minimum $\left(366 \mathrm{mg} \mathrm{l}^{-1}\right)$ at site 1.

242 Iron oxide removal from the IRIS tubes

243 The percentage area with depleted iron in a $15-\mathrm{cm}$ zone within the upper $30 \mathrm{~cm}$ of the

244 tube for all five sites varies from 0.5 to $95.1 \%$. It is also very variable between the five

245 tubes at a single site (Figure 3 and Table 3). The greatest variation in iron oxide removal

246 occurred at site 4 (standard deviation, SD, 39.7\%), at the southern margin of the lake

247 (Figure 1 and Table 3). Variability at the other sites was more modest (SDs from 2.9\%

248 to $11.5 \%$ ). The zones of the tubes where the iron oxide coating was chemically reduced

249 and removed were almost lacking iron oxide in some cases, whereas in others these

250 zones retained a thin coating of iron oxide that contrasted distinctly from the original

25I reddish brown colour (Figure 3). Occasionally, zones depleted of iron occurred above

252 the zero level line, i.e. the mark on the tube that corresponded to $0 \mathrm{~cm}$ or ground-level.

253 The patterns of iron oxide removal included: (i) spots, corresponding to reducing

254 conditions at microsites, (ii) area of continuous removal, corresponding to the reducing

255 conditions in a whole horizon, 3) doughnut-shaped depletion patterns (Jenkinson \&

256 Franzmeier, 2006) similar to that formed by bacterial cultures and (iv) linear depletion

257 patterns (Figure 3) often observed in areas with increased organic matter and microbial

258 activity (Vepraskas \& Faulkner, 2001) related to the occurrence of roots as a source of 259 organic matter (Jenkinson \& Franzmeier, 2006) because of the activity of 260 phytosiderosphores (Dorau et al., 2016). 

degree of reduction, Technical Standard (NTCHS). A minimum of three out of five IRIS tubes have $>30 \%$ of their coating removed in a zone $15-\mathrm{cm}$ long starting within 15 iron oxide depleted per month on the surface of the tube, ranges from 0.4 at site 1 (Ojos, Figure 1) to $12 \%$ at the neighbouring site 3 (Reguera). Iron monosulphides can form as black mottles on IRIS tubes by the rapid chemical reaction of soluble sulphide with the iron oxide coatings (Rabenhorst et al., 2010). The black FeS mottles were especially intense at sites 2 and 5, with a mean of 1.4 and $5 \%$, respectively (Table 3 ). Speciation of aqueous sulphide is $\mathrm{pH}$ dependent, and the alkaline $\mathrm{pH}$ of the calcareous soil (Table 2) suggests that the pore water sulphide is primarily present as hydrogen suphide (HS ${ }^{-}$) (Garrels \& Christ, 1965). Maximum percentage of black mottles per tube occurs at site 5, with a $12.2 \%$ cover of the whole tube (Table 3 ) and $19.2 \%$ of the upper $30 \mathrm{~cm}$ of the tube. It is likely that these represent minimum sulphide values for the tubes from site 5, because the black sulphide initially forms as a coating over the iron oxide coating (which strongly adheres to the tubing). However, if all of the iron oxide on the tube becomes converted to the black FeS (from large sulphide concentrations or over long periods of time), the FeS (without an undercoating of iron oxide) does not adhere to the tube and leaving the white tube exposed. Some parts of the white areas at the bottom of the tubes from site 5 appear like this (mostly dark grey and white with little or no iron oxide), Figure 3.

\section{Discussion}

284 The wet saline soil of the Gallocanta saline lake, which is subjected to intermittent flooding, shows evidence of the mobilization of iron and manganese oxides in exposed 
soil (Figure 2a) or even temporarily at the soil surface (Figure 2b). In spite of the subtle topography of the area (from 0.3 to $2.2 \mathrm{~m}$ of height difference among sites) the elevation appears to condition the degree of reduction expressed in the iron oxide removal from the IRIS tubes. The average percentage of iron oxide removed from 15 $\mathrm{cm}$ generally increases from $3 \%$ to $81 \%$ as the elevation decreases even if the groundwater depth when the tubes were installed increases (Table 1). The site 3 is an exception, with $0.6 \mathrm{~m}$ of relative elevation increase and an average iron oxide removal of $81 \%$ to $95 \%$, probably due to the surface water inflow from the Reguera intermittent stream into the lake, producing longer periods of soil saturation in this mouth zone. The neighboring sites 1 and 3 represent the minimum and maximum intensity of iron depletion, respectively. Both sites have saline soil and fresh groundwater (Table 1) and their level of soil OM does not seem to condition the removal of iron from the IRIS tubes. A high percentage of iron oxide coating removal also occurs at the soil of site 5 , which has a high OM content (up to $6.2 \%)$ and gypsum (21\% as mean) and where $\mathrm{NO}_{3}{ }^{-}$ is completely removed from groundwater (Table 1) by reduction to $\mathrm{N}_{2}$.

The vertical distribution of iron depleted zones along the tubes are not uniform (Figure 3) and shows a great variety of patterns similar to that described by Jenkinson \& Franzmeier (2006) in very different types of soils from a diversity of locations. Even in a single depleted area of the tubes Dorau et al. (2016) recognize gradients of reducing soil conditions.

The redox micromorphic pedofeatures show a redox gradient with soil depth, which accords with the overall pattern of iron oxide removal shown by field photographs of the IRIS tubes. The iron and manganese oxides in the surface horizon (Figure 2c) indicate alternating reducing-oxidizing conditions, which are favoured by the abundant coarse material and the more aerated soil microstructure. In contrast, iron 
3II sulphides only accumulate at depth (Figure 2d), which indicate that reducing conditions

312 predominate because of the finer microstructure that controls soil porosity. Iron

313 hypocoatings can be produced after several days of water saturation, whereas the

314 formation of iron sulphides (pyrite) indicates very wet and reducing conditions from

3I5 several months of water saturation (Lindbo et al., 2010).

316 Contemporary or relict micromorphological features may occur in the same

317 horizon (Lindbo et al., 2010), but because of tubes had been installed for several months

318 we recorded features that are actively forming. Based on the redox sequence

319 (Ponnamperuma, 1972) and their corresponding $E_{H}$ values summarized by Dorau \&

320 Mansfeldt (2015), all the sites studied have at least moderate reducing soil conditions

32I because exhibit iron oxide removal which indicates $E_{H}$ ranges from 100 to $-100 \mathrm{mV}$.

322 Sulphate reduction and FeS deposition $>0.2 \%$ at sites 2, 3 and 5 indicate that these sites

323 have strongly reducing soil conditions with $E_{H}$ values $<-100 \mathrm{mV}$, especially site 5,

324 which is at the lowest landscape position where iron sulphide deposits were maximum.

325 According to the categories proposed by Bartlett \& James (1995), soil at sites 2, 3 and 5

326 has a sulphidic redox status.

327 In contrast with other carbonate-rich environments (Stiles et al., 2010) and 328 laboratory observations (Couto et al, 1985), in Gallocanta Lake the expression of redox

329 features is not inhibited by the buffering capacity associated with the high content of 330 CCE (47\% as mean). Additionally, in contrast observations in other soils (Craft, 2001) 33I the availability of $\mathrm{NO}_{3}{ }^{-}$in groundwater does not appear to hamper iron reduction and 332 mobilization in these soils. It is likely, however, that these components may reduce the 333 rate of development and expression of redox features.

Although we observed minor reduction of iron oxide coatings after four weeks at 335 the lake floor (site 5), generally the time needed for tubes to show evidence of soil 
reducing conditions among all sites surrounding Gallocanta Lake was 27 weeks on average (Table 1), which was very long when compared with the time (days to weeks) required in non-carbonatic environments (Jenkinson \& Franzmaier, 2006; Dorau et al., 2016) or in controlled experiments (Rabenhorst et al., 2008; Dorau \& Mansfeldt, 2015). The effect of carbonate content was observed during soil incubation, where, despite the presence of oxidizable sulphide, the decrease in $\mathrm{pH}$ (down to 7.3 during the first two weeks before rising to slightly alkaline values, 7.8) was inhibited in those soils which had $17.4 \%$ and $37.6 \%$ of CCE (Table 2), similar to reports by Couto et al. (1985) under controlled conditions. However, the seasonal inundation observed in Gallocanta Lake suggests the occurrence of intermittent water saturation of soil, which is probably the main reason of the low reduction rate found at our soil. Additionally, the delay in reduction timeframes may also be affected by the high carbonate content. As already demonstrated by Dorau \& Mansfeldt (2015), the use of Mn-oxide coated tubes may improve the IRIS method by the preferential reductive dissolution of manganese over iron oxides, thus reducing the time of monitoring and enhancing the differences in intensity of reduction between sites.

There is no clear relationship between soil or groundwater composition (and salinity) and the degree of iron removal from IRIS tubes, despite an eight-fold range in iron oxidation is completely inhibited with $3 \%(\mathrm{wt} / \mathrm{vol})$ of $\mathrm{NaCl}\left(\cong 40 \mathrm{dS} \mathrm{m}^{-1}\right)$ under laboratory conditions (Cameron et al., 1984) whereas in the soil studied it occurs at much higher salinity (Table 1) indicating the complexity of natural conditions. This issue would require a fully experimental approach, i.e. controlled conditions only achievable in laboratory or microcosm experiments. This is beyond the scope of this paper. 

is high. Although continuous water table data are not available for the IRIS sites during the period of study, one can reasonably assume that the occurrence of shallow water table caused the development of anaerobic conditions and the reduction of iron oxide

365 from the IRIS tubes at sites 3 and 5, and probably at site 4. As introduced by Dorau et al. (2016), the monitoring of water tables in parallel to that of iron removal from IRIS

367 tubes would produce more meaningful data for normalizing the iron removal per unit of time (day or week) when water tables are near (within $30 \mathrm{~cm}$ of) the soil surface. However, the intensity and duration of reducing soil conditions should be considered as conditioned by multiple factors, and not only by the water table depth or other single soil parameter. The organic matter type and content, $\mathrm{pH}$, soil temperature, and microbial

372 community can vary between sites, making difficult to predict or normalize iron removal, even within a wetland.

\section{Conclusions}

376 This study demonstrates that IRIS tubes are of value to document the development of

377 reducing conditions in saline and carbonate-rich wet soil from research at Gallocanta

378 Lake where the water level fluctuates seasonally and annually. The identification of 379 current reduction in the soil of different geomorphic and edaphic units around the lake confirms that previously observed macro and micromorphological redoximorphic

38I features are probably developing at present in spite of the intermittent dryness of the lake. The alkaline conditions with waterlogging grant novelty to our work. sites show little association with soil composition or salinity, but seem to be related mainly to subtle differences in topography that control when the soil becomes saturated 
386

387

388

389

390

391

392

393

394

395

396

397

398

399

400

401

402

403

404

405

406

407

408

409

and reducing conditions persist. Interpretation of the processes and factors responsible for the differences in the amount and patterns of iron depletion from the IRIS tubes between sites remain unsolved. This critical limitation of our field approach also poses a subject for future research which should be complemented with laboratory or microcosm experiments.

\section{Acknowledgements}

This work is a result of the research projects PCIN-2014-106, funded by the Spanish Government, and I-COOP-2016SU0015, funded by the Spanish National Research Council (CSIC). We acknowledge the data provided by the Spanish Meteorological Agency (AEMET) after contract no L2 990130734. E. Luna was financed by a fellowship from the Aragón Government, Spain. Two anonymous reviewers and the Editor helped to improve the paper.

\section{References}

Artieda, O., Herrero, J. \& Drohan, P.J. 2006. A refinement of the differential water loss method for gypsum determination in soils. Soil Science Society of America Journal, 70, 19321935.

Bartlett, R.J. \& James, B.R. 1995. System for categorizing soil redox status by chemical field testing. Geoderma, 68, 211-218.

Cameron, F.J. Jones, M.V. \& Edwards, C. 1984. Effects of salinity on bacterial iron oxidation. Current Microbiology, 10, 353-356.

Castañeda, C. \& Herrero, J. 2008. Assessing the degradation of saline wetlands in an arid agricultural region in Spain. Catena, 72, 205-213. 
410 Castañeda, C., Gracia, F.J., Luna, E. \& Rodríguez-Ochoa, R. 2015. Edaphic and 4II geomorphic evidences of water level fluctuations in Gallocanta Lake, NE Spain. 4I2 Geoderma, 239-240, 26-279.

413 Castenson, K.L. \& Rabenhorst, M.C. 2006. Indicator of reduction in soil (IRIS): 4I4 Evaluation of a new approach for assessing reduced conditions in soil. Soil Science $415 \quad$ Society of America Journal, 70, 1222-1226.

416 Comín, F., Alonso, M., Lopez, P. \& Comelles, M. 1983. Limnology of Gallocanta Lake, 417 Aragon, northeastern Spain. Hydrobiologia, 105, 207-221.

418 Costantini, E.A.C., Pellegrini, S., Bucelli, P., Storchi, P., Vignozzi, N., Barbetti, R. \& 419 Campagnolo, S. 2009. Relevance of the Lin's and Host hydropedological models to 420 predict grape yield and wine quality. Hydrology and Earth System Sciences, 13, 421 
Dorau, K., Eickmeier, M. \& Mansfeldt, T. 2016. Comparison of manganese and iron oxide-coated redox bars for characterization of the redox status in wetland soils. Wetlands, 36, 133-141.

García-Vera, M.A. \& Martínez-Cob, A. 2004. Evolución del contenido de humedad y de la tasa de evaporación en humedales: aplicación a la Laguna de Gallocanta. 2004-PH-14-I, Zaragoza, Spain (In Spanish). URL http://hdl.handle.net/10261/2976 [accessed on 15 Nov 2016].

Garrels, R.M. \& Christ, C.L. 1965. Solutions, Minerals, and Equilibria. Harper and Row, New York, NY.

Grealish, G., Fitzpatrick, R. \& Shand, P. 2010. Acid sulphate soil toposequences in wetlands of the Lower River Murray. In: Soil Solutions for a Changing World, Proceedings of the 19th Congress of Soil Science, pp 17-20, 1-6 August, Brisbane, Australia. Published on DVD.

Guilloré, P. 1985. Méthode de Fabrication Mécanique et en Série des Lames Minces, 3rd edn, Institut National Agronomique, Paris-Grignon, France (In French).

Heanes, D.L. 1984. Determination of total organic-C in soils by an improved chromic acid digestion and spectrophotometric procedure. Communications in Soil Science and Plant Analysis, 15, 1191-1213.

IUSSWorking Group WRB 2015. World Reference Base for Soil Resources 2014. International Soil Classification System for Naming Soils and Creating Legends for Soil Maps. World Soil Resources Report No 106, FAO, Rome, Italy.

Jenkinson, B.J. \& Franzmeier, D.P. 2006. Development and evaluation of Iron-coated tubes that indicate reduction in soils. Soil Science Society of America Journal, 70, $183-191$. 
457 King, G.M. \& Garey, M.A. 1999. Ferric Iron reduction by bacteria associated with the roots of freshwater and marine macrophytes. Applied and Environmental Microbiology, 65, 4393-4398.

460 Luna, E., Castañeda, C., Gracia, F.J. \& Rodríguez-Ochoa, R. 2016. Late Quaternary pedogenesis of lacustrine terraces in Gallocanta Lake, NE Spain. Catena, 147, 372385.

Lindbo, D.L., Stolt, M.H. \& Vepraskas, M.J. 2010. Redoximorphic features. In: Interpretation of Micromorphological Features of Soils and Regoliths. Their Relevance for Pedogenic Studies and Classifications (eds G. Stoops, V. Marcelino \& F. Mees), pp. 129-147, Elsevier, Oxford, UK.

Ponnamperuma, F.N. 1972. The chemistry of submerged soils. Advances in Agronomy, 24, 29-96.

Rabenhorst, M.C. 2008. Protocol for using and interpreting IRIS tubes. Soil Survey Horizons, 49, 74-77.

Rabenhorst, M.C. 2012. Simple and reliable approach for quantifying IRIS tube data. Soil Science Society of America Journal, 76, 307-308.

Rabenhorst, M.C. \& Burch, S.N. 2006. Synthetic iron oxides as an indicator of reduction in soils (IRIS). Soil Science Society of America Journal, 70, 1227-1236.

Rabenhorst, M.C., Bourgault, R.R. \& James, B.R. 2008. Iron oxyhydroxide reduction in simulated wetland soils: Effects of mineralogical composition of IRIS paints. Soil Science Society of America Journal, 72, 1838-1842.

Rabenhorst, M.C., Megonigal, J.P. \& Keller, J. 2010. Synthetic iron oxides for documenting sulphide in marsh pore water. Soil Science Society of America Journal, 74, 1383-1388. 
Rodó, X., Giralt, S., Burjachs, F., Comín, F., Tenorio, R.G. \& Julià, R. 2002. Highresolution saline lake sediments as enhanced tools for relating proxy paleolake records to recent climatic data series. Sedimentary Geology, 148, 203-220.

Schoeneberger, P.J., Wysocki, D.A., Benham, E.C. \& Soil Survey Staff. 2012. Field Book for Describing and Sampling Soils, Version 3.0. Natural Resources Conservation Service, National Soil Survey Center, Lincoln, NE.

Schütt, B. 1998. Reconstruction of Holocene paleoenvironments in the endorheic basin of Laguna de Gallocanta, Central Spain by investigation of mineralogical and geochemical characters from lacustrine sediments. Journal of Paleolimnology, 20, $217-234$.

Snyder, M., Taillefert, M. \& Ruppel. C. 2004. Redox zonation at the saline-influenced boundaries of a permeable surficial aquifer: Effects of physical forcing on the biogeochemical cycling of iron and manganese. Journal of Hydrology. 296, 164 178.

Soil Survey Staff. 2014. Keys to Soil Taxonomy, 12th edn,. U.S. Department of Agriculture, Natural Resources Conservation Service, Washington, DC.

Stiles, C.A., Dunkinson, E.T., Ping, C.L. \& Kidd, J. 2010. Initial field installation of manganese indicators of reduction in soils, Brooks Range, AK. Soil Survey Horizons, 51, 102-107.

Stoops, G. 2003. Guidelines for Analysis and Description of Soil and Regolith Thin Sections. Soil. Science Society of America, Inc., Madison, WI.

USDA-NRCS. 2010. Field Indicators of Hydric soils in the United States, version 7.0 (eds L.M. Vasilas, G.W. Hurt \& C.V. Noble). USDA, NRCS, in cooperation with the National Technical Committee for Hydric Soils. Washington, DC. 
505 Veneman, P.L.M., Vepraskas, M.J. \& Bouma, J. 1976. The physical significance of soil 506 mottling in a Wisconsin toposequence. Geoderma, 15, 103-118.

507 Vepraskas, M.J. \& Faulkner, S.P. 2001. Redox chemistry of hydric soils. In: Wetland 508 Soils: Genesis, Hydrology, Landscapes, and Classification (eds J.L. Richardson \& 509 M.J. Vepraskas), pp. 85-106. CRC Press, LLC, Boca Raton, FL.

5I0 Williams, W.D. 2002. Environmental threats to salt lakes and the likely status of inland 5II saline ecosystems in 2025. Environmental Conservation, 29, 154-167.

512 


\section{$513 \quad$ Figure captions}

5 I4 Figure 1 Colour-shaded LiDAR-derived digital elevation model of Gallocanta Lake 515 with major contour lines and locations of the IRIS tubes.

516 Figure 2 Evidence of iron and manganese mobilisation in Gallocanta Lake: (a) in

517 recently exposed soil at site 4 , (b) at the soil surface in nearby areas subjected to 518 intermittent flooding. Thin sections show redox micromorphic pedofeatures 519 associated with voids (v), (c) manganese oxide (Mn) and iron-manganese oxide 520 (Fe/Mn) impregnated hypocoatings observed with plane polarized light, Ayzg and 52I (d) framboidal iron sulphide (FeS) coating observed with oblique incident light, $522 \quad 2 \mathrm{Cyg} 3$.

523 Figure 3 Photographs taken in the field of five replicate IRIS tubes from each site when 524 they were extracted at the completion of the study.

525 Figure 4 Photographs of IRIS tubes taken in the laboratory which show the upper 30 $526 \mathrm{~cm}$ of the tubes. Black areas correspond to the iron oxide coating removed and red 527 boxes indicate the $15-\mathrm{cm}$ section of the $30-\mathrm{cm}$ tube with maximum removal of iron $528 \quad$ oxide coating. 


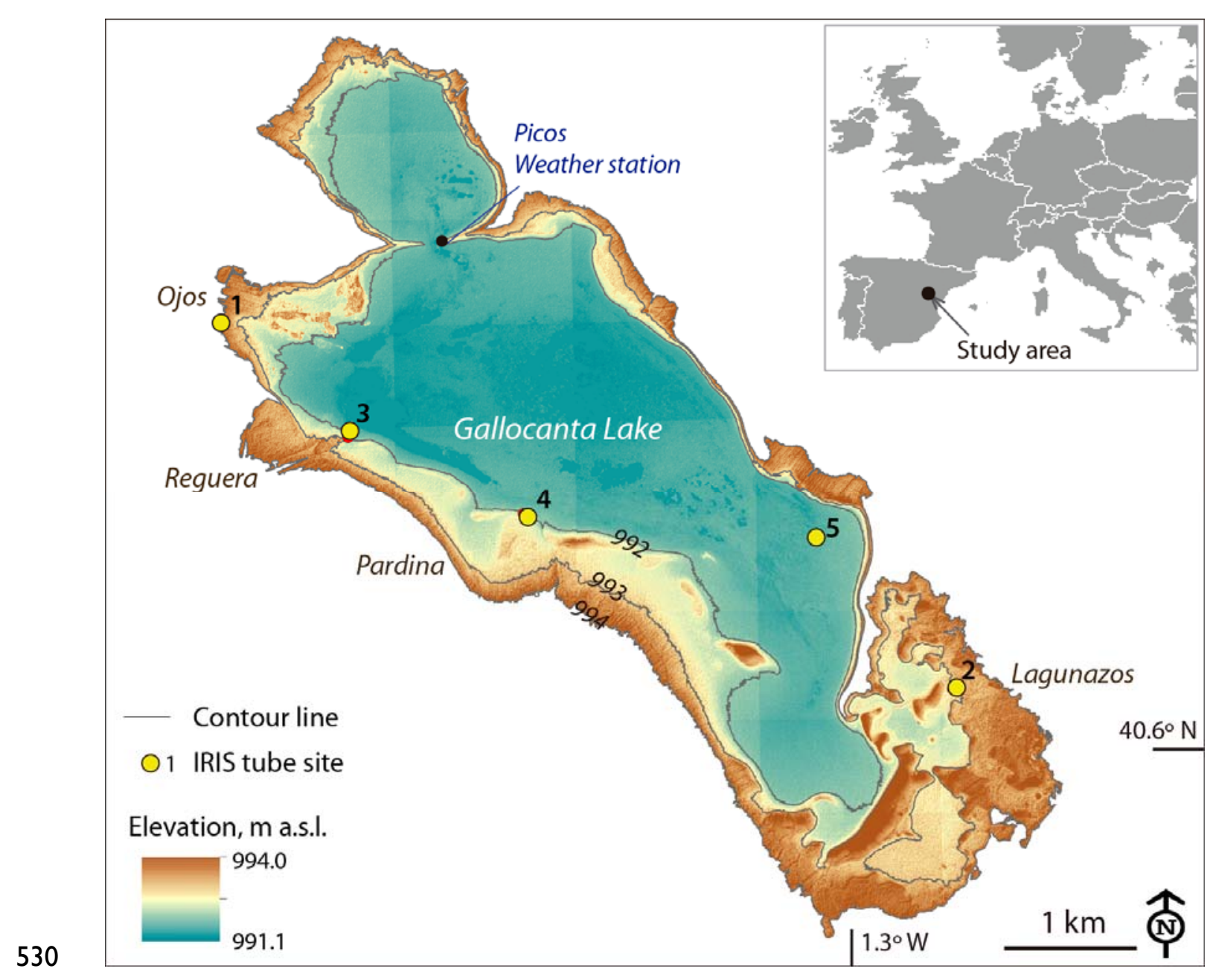

531 

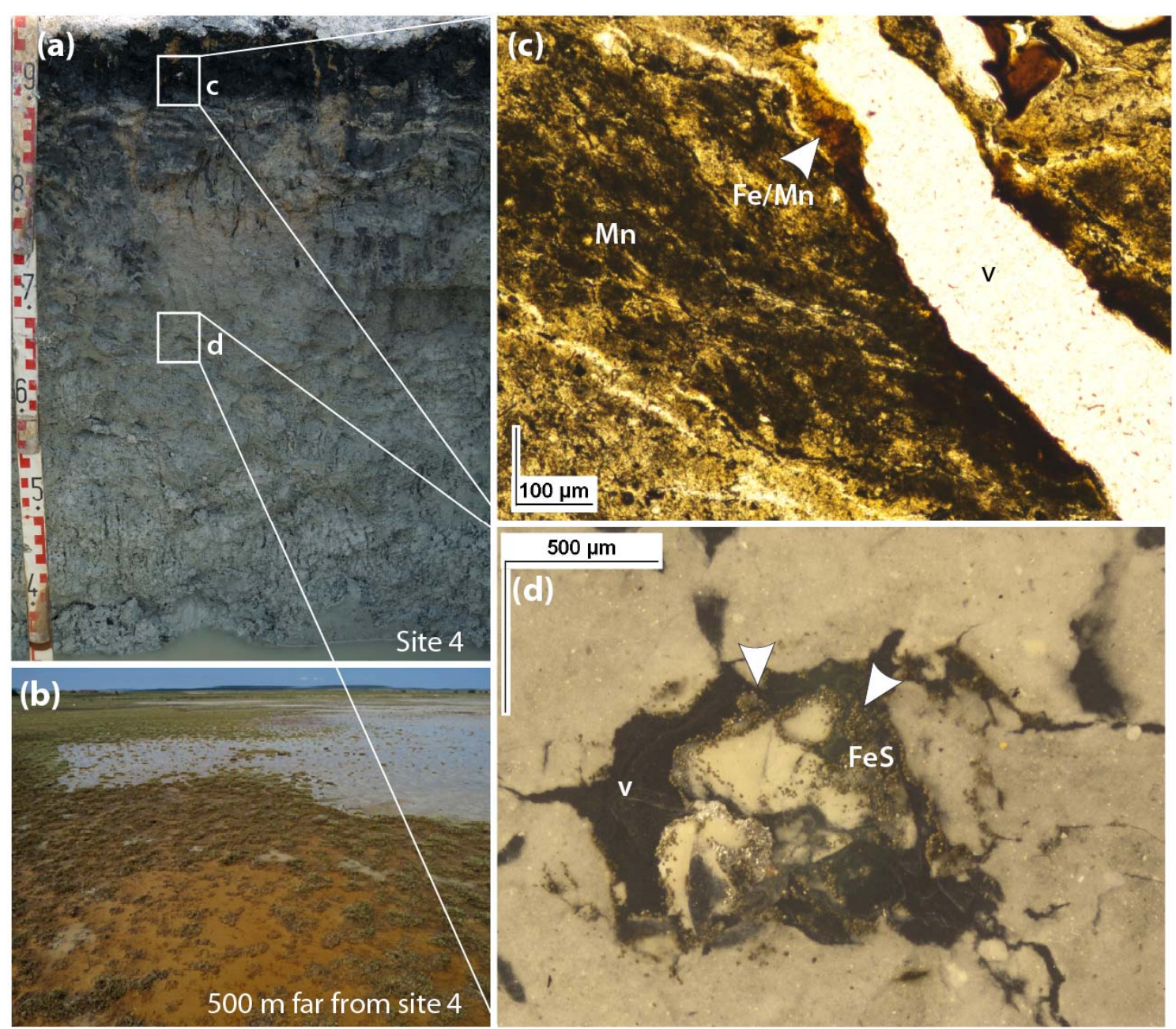

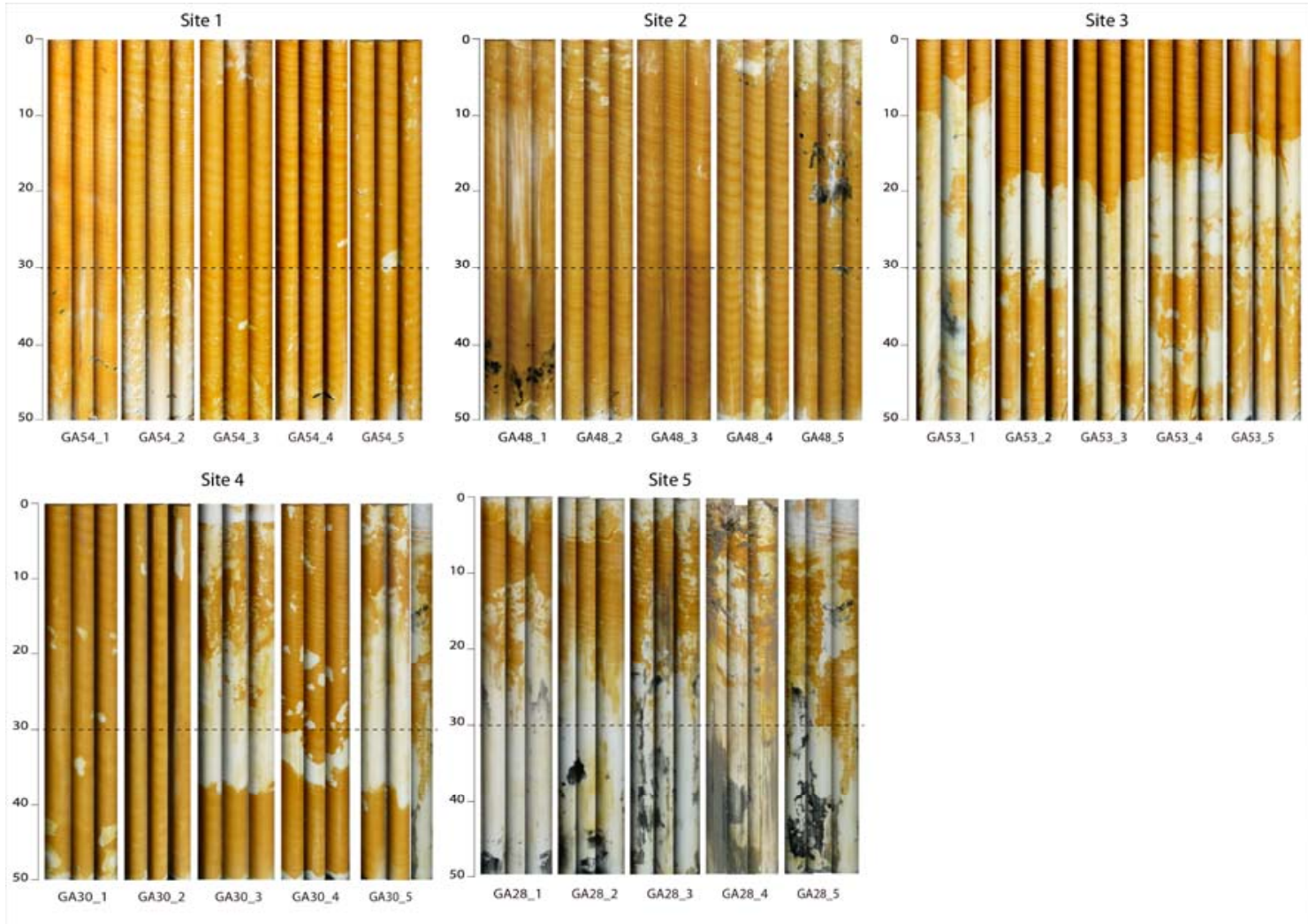

533

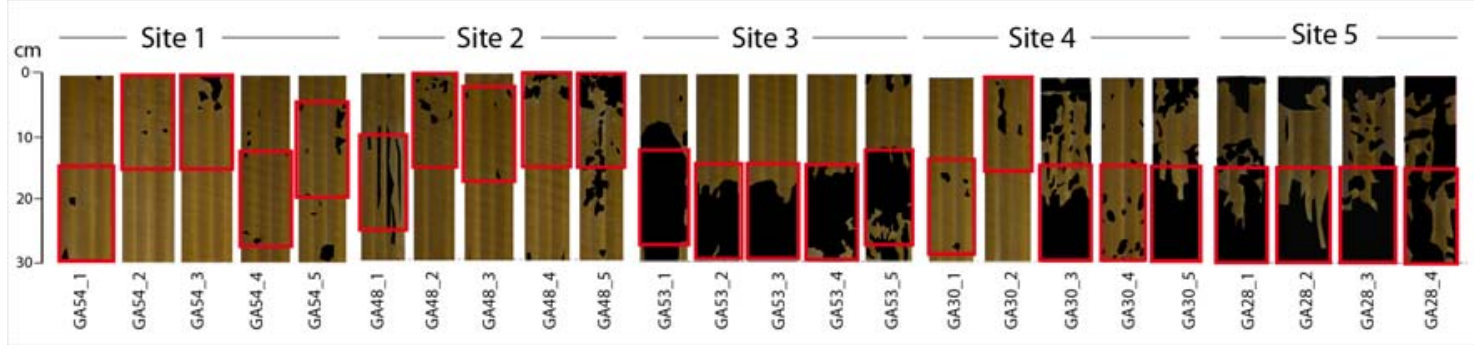


Table 1 Selected characteristics of sampled sites and groundwater

\begin{tabular}{|c|c|c|c|c|c|c|c|c|c|c|c|c|c|c|c|}
\hline \multirow{2}{*}{ Site } & \multirow{2}{*}{$\begin{array}{l}\text { Refere } \\
\text { nce } \\
\text { name }\end{array}$} & \multirow{2}{*}{$\begin{array}{l}\text { Elevati } \\
\text { on / } \\
\text { m } \\
\text { a.s.l. }\end{array}$} & \multirow{2}{*}{$\begin{array}{l}\text { Geomorphi } \\
\text { c unit }\end{array}$} & \multicolumn{2}{|c|}{ Soil classification } & \multirow{2}{*}{ Landcover } & \multirow{2}{*}{$\begin{array}{l}\text { Total } \\
\text { numb } \\
\text { er of } \\
\text { weeks }\end{array}$} & \multirow{2}{*}{$\begin{array}{l}\text { Ground } \\
\text { water } \\
\text { depth } \\
/ \mathrm{cm}\end{array}$} & \multirow{2}{*}{$\mathrm{pH}$} & \multirow{2}{*}{$\begin{array}{l}\mathrm{EC}^{\mathrm{c}} \\
/ \mathrm{dS} \mathrm{m}^{-1}\end{array}$} & \multirow[t]{2}{*}{$\mathrm{NO}_{3}^{-\mathrm{d}}$} & \multirow[t]{2}{*}{$\mathrm{SO}_{4}{ }^{2-}$} & \multirow{2}{*}{$\begin{array}{c}\mathrm{HCO}^{-} \\
/ \mathrm{mg} \mathrm{l}^{-1}-\end{array}$} & \multirow[t]{2}{*}{$\mathrm{NH}_{4}^{+}$} & \multirow[t]{2}{*}{$\mathrm{Mg}^{2+}$} \\
\hline & & & & $\mathrm{ST}^{\mathrm{a}}$ & $\mathrm{WRB}^{\mathrm{b}}$ & & & & & & & & & & \\
\hline 1 & GA54 & 994.0 & $\begin{array}{l}\text { NW } \\
\text { lacustrine } \\
\text { terrace }\end{array}$ & ND & & $\begin{array}{l}\text { Saline } \\
\text { grasses }\end{array}$ & 22 & -10 & 8.1 & 2.21 & 0.436 & 442 & 366 & 0.358 & 158 \\
\hline 2 & GA48 & 992.8 & $\begin{array}{l}\mathrm{SE} \\
\text { lacustrine } \\
\text { terrace }\end{array}$ & $\begin{array}{l}\text { Typic } \\
\text { Calcixerept }\end{array}$ & $\begin{array}{l}\text { Haplic } \\
\text { Calcisol }\end{array}$ & $\begin{array}{l}\text { Rush salt } \\
\text { marshes }\end{array}$ & 34 & -23 & 6.9 & 17.5 & 19.4 & 5487 & 854 & 1.97 & 1295 \\
\hline 3 & GA53 & 992.4 & $\begin{array}{l}\text { Submerged } \\
\text { silt-sand } \\
\text { deposit }\end{array}$ & ND & & $\begin{array}{l}\text { Reed } \\
\text { formations }\end{array}$ & 22 & -27 & 8.2 & 1.97 & 0.286 & 216 & 610 & 0.440 & 99.4 \\
\hline 4 & GA30 & 992.1 & $\begin{array}{l}\text { Sandy } \\
\text { barrier }\end{array}$ & $\begin{array}{l}\text { Typic } \\
\text { Aquisalid }\end{array}$ & $\begin{array}{l}\text { Gleyic } \\
\text { Solonchak }\end{array}$ & Bare soil & 30 & -28 & 7.1 & 58.5 & 26.5 & 10594 & 549 & 7.85 & 4893 \\
\hline 5 & GA28 & 991.8 & Lake bed & $\begin{array}{l}\text { Gypsic } \\
\text { Aquisalid }\end{array}$ & $\begin{array}{l}\text { Gypsic } \\
\text { Gleyic } \\
\text { Solonchak }\end{array}$ & Bare soil & 30 & -100 & 6.7 & 104 & n.d. & 29408 & 488 & 20.6 & 11751 \\
\hline
\end{tabular}

${ }^{\mathrm{a}}$ USDA Soil Taxonomy (Soil Survey Staff, 2014). ND= not determined.

${ }^{\mathrm{b}}$ World Reference Base (IUSS Working Group WRB, 2015).

${ }^{\mathrm{c}}$ Electrical conductivity.

n.d. = not detected. 
Table 2 Main characteristics of the upper $50 \mathrm{~cm}$ of soil at the IRIS tubes sites

\begin{tabular}{|c|c|c|c|c|c|c|c|c|c|c|c|c|c|c|c|}
\hline \multirow{2}{*}{$\begin{array}{l}\text { Depth } \\
/ \mathrm{cm}\end{array}$} & \multirow{2}{*}{ Horizon } & \multicolumn{2}{|c|}{ Munsell colour (Moist) } & \multirow{2}{*}{$\begin{array}{l}\mathrm{pH} \\
1: 2.5\end{array}$} & \multirow{2}{*}{$\begin{array}{l}\mathrm{pH} \\
\text { paste }\end{array}$} & \multirow{2}{*}{$\begin{array}{l}\mathrm{EC} 1: 5^{\mathrm{a}} \\
-/ \mathrm{dS} \mathrm{m}\end{array}$} & \multirow{2}{*}{$\begin{array}{l}\mathrm{ECe}^{\mathrm{b}} \\
-1\end{array}$} & \multirow[t]{2}{*}{$\mathrm{CCE}^{\mathrm{c}}$} & \multirow[t]{2}{*}{ Gypsum } & \multirow[t]{2}{*}{$\mathrm{OM}^{\mathrm{d}}$} & \multirow{2}{*}{$\begin{array}{l}\text { Gravels } \\
-\quad 1 \% \\
\end{array}$} & \multirow[t]{2}{*}{ Sand } & \multirow[t]{2}{*}{ Silt } & \multirow{2}{*}{ Clay } & \multirow{2}{*}{$\begin{array}{l}\text { USDA textural } \\
\text { class }\end{array}$} \\
\hline & & Matrix & Mottles & & & & & & & & & & & & \\
\hline \multicolumn{16}{|c|}{ Site 1 (GA54), auger hole } \\
\hline $0-25$ & & & & 7.6 & & 1.2 & 21.3 & 49.9 & 3.7 & 5.8 & 0.6 & 37.8 & 42.2 & 20.0 & Loam \\
\hline $25-50$ & & & & 7.9 & & 0.6 & 19.1 & 49.9 & 2.9 & 3.8 & 0.9 & 26.0 & 44.5 & 29.4 & Clay loam \\
\hline \multicolumn{16}{|c|}{ Site 2 (GA48), auger hole } \\
\hline $0-25$ & & & & 8.3 & & 0.3 & 18.1 & 28.9 & 3.6 & 1.1 & 1.9 & 34.5 & 38.3 & 27.2 & Clay loam \\
\hline $25-50$ & & & & 8.1 & & 0.8 & 19.9 & 31.7 & $<2.0$ & 0.4 & 2.6 & 35.4 & 41.6 & 23.0 & Loam \\
\hline \multicolumn{16}{|c|}{ Site 3 (GA53), auger hole } \\
\hline $0-25$ & & & & 7.9 & & 0.7 & 19.3 & 45.4 & $<2.0$ & 0.4 & 30.6 & 53.3 & 15.0 & 31.6 & Sandy clay loam \\
\hline $25-50$ & & & & 8.0 & & 0.6 & 19.1 & 45.1 & $<2.0$ & 0.4 & 23.5 & 34.7 & 29.8 & 35.5 & Clay loam \\
\hline \multicolumn{16}{|c|}{ Site 4 (Pedon GA30) } \\
\hline $0-10$ & $\mathrm{Ag}$ & $2.5 \mathrm{Y} 6 / 2$ & $7.5 \mathrm{YR} 6 / 6$ & & 8.3 & 9.4 & 67.7 & 37.6 & 4.4 & 0.8 & 0.8 & 61.2 & 18.5 & 20.4 & Sandy clay loam \\
\hline $10-25$ & $2 \mathrm{Cg} 1$ & $2.5 Y 6.5 / 1.5$ & $10 \mathrm{YR} 6 / 6$ & & 8.1 & 8.3 & 39.3 & 58.7 & 3.8 & 0.5 & & 14.1 & 49.0 & 36.9 & Silty clay loam \\
\hline $25-50$ & $2 \mathrm{Cg} 2$ & $2.5 Y 7 / 1.5$ & & & 8.1 & 4.0 & 25.7 & 69.7 & 2.2 & 0.5 & & 23.6 & 33.3 & 43.1 & Clay \\
\hline \multicolumn{16}{|c|}{ Site 5 (Pedon GA28) } \\
\hline $0-6 / 10$ & Ayzg & 10B $2.5 / 1$ & & & 7.9 & 65.8 & 182 & 18.4 & 27.1 & 5.8 & & 79.8 & 15.5 & 4.7 & Loamy sand \\
\hline $\begin{array}{l}6 / 10- \\
14 / 16\end{array}$ & Cyg1 & $\begin{array}{l}10 \mathrm{~B} 2.5 / 1-5 \mathrm{Y} \\
6 / 1\end{array}$ & $5 Y 6 / 1$ & & 8.5 & 36.2 & 146 & 29.3 & 14.5 & 6.2 & & 62.4 & 25.1 & 12.4 & Sandy loam \\
\hline $14 / 16-24$ & Cyg2 & 10B 5.5/1 & 10B $5.5 / 2$ & & 8.6 & 23.7 & 104 & 36.6 & 17.0 & 3.9 & & 44.0 & 31.6 & 24.4 & Loam \\
\hline $24-42$ & $2 \mathrm{Cyg} 3$ & $2.5 \mathrm{GY} 6 / 1$ & 10B $4.5 / 1$ & & 8.2 & 23.2 & 100 & 28.0 & 28.6 & 3.4 & & 44.8 & 26.4 & 28.8 & Clay loam \\
\hline $42-50$ & $2 \mathrm{Cyg} 4$ & $7.5 \mathrm{GY} 6 / 1$ & & & 7.9 & 22.6 & 97.5 & 52.0 & 5.7 & 1.2 & 0.8 & 15.0 & 40.2 & 44.7 & Silty clay \\
\hline
\end{tabular}

${ }^{a}$ Electrical conductivity of the soil:water 1:5 extract.

${ }^{b}$ Electrical conductivity of the saturation extract; ECe for sites 1 to 4 was estimated by regression between EC1:5 and ECe of samples from GA28 and GA30 (Castañeda et al., 2015).

${ }^{\mathrm{c} C a l c i u m}$ carbonate equivalent.

dOrganic matter. 
Table 3 Percentage of iron oxide depleted from a $15-\mathrm{cm}$ zone of the IRIS tubes within the upper $30 \mathrm{~cm}$ of the soil surface (the main zone of interest when considering hydric soil issues) and percentage of black FeS mottles deposited on the tube

\begin{tabular}{llllll}
\hline Iron oxide removal on a $15-\mathrm{cm}$ zone & Site 1 & Site 2 & Site 3 & Site 4 & Site 5
\end{tabular}

\section{Number of IRIS tubes}

Total 5

5

5

5

4

With $\geq 30 \%$ iron oxide coating removal

0

1

5

2

4

Surface removal / \%

Mean

12.3

80.8

33.9

70.4

Median

8.2

75.8

8.9

69.6

Standard deviation

11.5

8.8

39.7

9.1

Maximum

7.1

30.4

95.1

86.8

80.9

Minimum

0.5

1.0

74.1

2.1

61.5

Range

6.6

29.4

21.0

84.7

19.4

Monthly rate

0.4

1.3

12.0

3.9

Percentage of black FeS mottles ${ }^{a}$

T1

$\mathrm{T} 2$

T3

T4

T5

Mean(SD)
0.4

0.4

0

0.2

0.2

$0.2(0.1)$
1.8

0.1

5.4

0.2

0

0

0.4

0.1

0

0

12.2

2.3

0.2

3.6

0.1

0.1

4.6

${ }^{\mathrm{a}} \mathrm{FeS}$ mottles that occurred along the full 50-cm length of the IRIS tubes at the time they were extracted from the field; T, tube; SD, standard deviation. 